\title{
SWOT Analysis Based on Cooperative Learning Course Teaching Model Reform
}

\author{
Li-Jun LIU* \\ Shandong Technology and Business University, Yantai, China \\ Ilj2002-1@163.com \\ ${ }^{*}$ Corresponding author
}

Keywords: Cooperative learning, SWOT analysis, Teaching design, Autonomous learning.

\begin{abstract}
It is an inevitable choice for college teaching reform to cultivate application-oriented talents to meet social needs. It is an effective way of applied talent training through establishing the cooperative study group form, reforming teaching mode, cultivating students' communication ability, strain capacity, team spirit and innovation ability. In this paper, using the SWOT analysis method, combining with the teaching model reform pilot curriculum, analyzing the advantages and disadvantages of cooperative learning, the opportunities and challenges, it is aimed at summing up experience, promoting the continuous improvement of the cooperative learning teaching mode and practice.
\end{abstract}

\section{Introduction}

The cultivation of application-oriented talents is a major subject in the teaching reform of colleges and universities, and cooperative learning teaching mode is an effective way to cultivate application-oriented talents. Characterized by cooperative learning research type teaching mode is the form of building a learning team, cultivating students' innovation consciousness and innovation ability, critical thinking and team cooperation spirit [1]. Through the teaching contents, teaching organization form, teaching design, teaching evaluation methods, it is to realize the transition from teacher teaching to guided learning, from passive acceptance of knowledge to active acceptance of critical thinking and innovation ability, from the process evaluation of knowledge mastery to the ability, and promote students interest and specialty, will, personality traits such as bearing and the formation and development of comprehensive quality.

Taking the teaching reform course of facility planning and logistics analysis as an example, This paper explores the reform of teaching methods characterized by cooperative learning in order to cultivate application-oriented talents to meet social needs. By using SWOT tools to analyze the advantages and disadvantages, opportunities and challenges of cooperative learning teaching model [2], enhance the understanding of cooperative learning and improve teaching design and teaching skills.

\section{The Advantage of Cooperative Learning Teaching Model}

\section{Students' Learning Efficiency And Academic Performance Have been Greatly Improved}

In the learning process, besides the interaction between teachers and students, it is more important to give full play to the interaction between students and students. For example, about logistics and supply chain relationship problems, the students play their respective strengths, help each other, inspire each other, reach consensus within the group, select the representative and exchange the learning results of each group. In cooperative learning, teachers act as guides, consultants, participants and partners, leave a lot of class time for students and make them a chance to play each other, improve together, found the problem by themselves, and try to solve the problem. Teachers should choose some teaching contents to be solved by the study group, so that students can take learning as a pleasure and create a desire for knowledge. 


\section{Cooperative Learning Model Is Conducive to Creating a Relaxed and Democratic Classroom Atmosphere}

Teachers are the organizers, mentors and participants of student learning activities. A very important task for teachers is to provide students with the space and time for cooperation and communication, which is the most important learning resource. In the teaching practice of facilities planning and logistics analysis, classroom teaching organization forms of the individual learning, sit at the same table, group communication, team cooperation and international exchange and the communication of the class are adopted, these forms of organization are the time for students to create the cooperation and communication. At the same time, in order to promote teaching democracy, teachers should actively encourage students to question and raise their views in the analysis and discussion, so as to make students feel liberated and relaxed in cooperative learning. This way is helpful for students to boldly ask questions in class, speak freely, brainstorming, forming loose democratic classroom atmosphere, a good learning environment is created for the successful cooperation between students, between teachers and students.

\section{The Teaching Mode Plays a Significant Role in Promoting Students to Form a Good Non-cognitive Psychological Quality}

The implementation process of facility planning and logistics analysis based on cooperative learning is realized by setting up the study group. Students are divided into several groups according to the students' knowledge, ability to learn and traits of character, the students are a group of eight to ten, the study group is led by a student who has a good foundation and has some organizational skills. There is no obvious difference between the groups, so as to achieve a balance, achieve the heterogeneity within the group, the group is homogeneous. The homogeneity between the groups creates the conditions to ensure fair competition among the groups and ensures the rationality between the group and the group. Everyone is required to comment and speak in class during group discussion, the participation rate of each student is an important basis for the assessment of cooperative learning quality, so as to enhance the cohesion of study group, to avoid situations where a person or a few people are arranged, make the cooperative learning become a mere formality. At the same time, the study group has a clear division of labor, set up the student's personal goals and team goals, let every student to take responsibility in the group discussion, to evaluate each student's performance scientifically, to motivate learning motivation and arouse the enthusiasm of students' thinking. In this context, teachers can guide students through discussion and group study, so as to achieve the effect that students can't achieve alone.

\section{The Disadvantage of Cooperative Learning Teaching Model}

\section{The Study of Teaching Design and Teaching Method Is Insufficient}

It has become an urgent problem for colleges and universities to carry out the teaching design based on student and cooperative learning activities in cooperative learning teaching practice. First of all, the teaching goal is the key to the teaching design, which directly affects the teaching content, teaching method, teaching media, teaching evaluation and teaching effect. The design of teaching objective is to realize the transformation between the desired goal of the teaching system and the goal that learners can achieve, this transformation is limited by various factors, such as the designer's understanding of the teaching goals, means and methods, etc. Therefore, it is very important to analyze the teaching objectives. Secondly, teaching strategy is an integral part of teaching design. Teaching strategies are the teaching procedures and implementation measures designed to accomplish teaching objectives and meet students' cognitive needs in specific teaching situations. It contains three layers of meaning: the teaching strategy belongs to the teaching design, teaching strategies are based on specific teaching objectives and teaching targets, teaching strategy there are both concept of function and operating functions. Improving teaching strategies can help teachers improve teaching quality. The goal of teaching is to solve the problem of "what to teach" and the teaching strategy to solve the problem of "how to teach". Third, teaching evaluation is the guarantee of teaching design. Teaching evaluation is based on certain goals and standards, adopting scientific attitude and method, and judging the process and result of teaching activities and the quality and quantity of the development and change of the educatees. For example, in 
the curriculum teaching design of facilities planning and logistics analysis course, according to the teaching content of the course covers, evaluation methods are stage, sub - module, diversified, each module according to its important degree give different scores, including: course work (10\%), group assignments (30\%), the course test $(60 \%)$.

\section{The Teaching Process and the Teacher's Role Are Blurred}

One of the important issues of cooperative learning is the change of teacher's role. In the traditional teaching mode of teacher speaking and listening to students, teachers should transfer the prepared knowledge to the students, and the students rarely ask questions, and there is little interaction between teachers and students. In the cooperative learning teaching mode, the teacher is not only the imparter of knowledge, but also thought enlightener and attentive observer, classroom activity of catalyst, information consultant, even a schoolmate. Especially in the seminar, and each group's research project involves many aspects of knowledge, students have many specific issues to the teachers and students together to solve, so teachers in the classroom are faced with the challenge of large,and always worried about their lack of knowledge, also forced the teacher after class to do further study.

In the process of implementation of cooperative learning, teachers' professional knowledge is not enough, also need to build teams with hands-on experience, to grasp the principle of cooperative learning and skills, to explore the effective organization method of cooperative learning. That is to say, cooperative learning is not simply to divide students into study groups, teachers must be able to create the environment, cause the student to establish the care about each other, mutual commitment, but also teach them social skills of cooperation, through the program and the result feedback to understand team approach to achieve objectives and maintain effective working relationship between members, all these require the teacher to carry on the new study and the continuous discussion. At the same time, the teachers and students have very big effect on cooperative, each course is best formed by two or more teaching teams, a number of teachers cooperate to complete the tasks such as curriculum construction, theoretical teaching, small class discussion, after-school tutoring and reading assignments. Cooperative learning teaching reform will surely need a teaching team in the structure and level of professional knowledge, innovation and dedication, and constantly improve their work.

\section{Institutional Guarantee and Evaluation Mechanism Are Deficient}

The teaching reform of cooperative learning should not only have scientific teaching design, but also need strong policy support.Therefore, colleges and universities should construct an evaluation mechanism for teaching reform, and guide and guarantee the effective implementation of cooperative learning teaching reform. These measures include to support the pilot reform programme in the form of a project, to support professional teaching reform in the form of innovative experimental area, special rewards for evaluating excellent teaching and innovation teams and projects with outstanding achievements.Only by innovating the learning evaluation mechanism of students and the teaching evaluation mechanism of teachers can we guide and motivate teachers and students to adapt to the teaching reform. It is necessary to change the learning evaluation method which has long been used to assess the knowledge of the examination paper. Diversified and procedural comprehensive evaluation methods should be adopted. The school pays more attention to students' growth and progress, and guides students to strengthen communication and cooperation. At the same time, also want to change the traditional evaluation standard of teachers' teaching effect, the classroom is no longer a teacher performance stage, should be to improve the student's ability of learning degree as the main content of the evaluation of teachers, focusing on incentives and development of teachers, lead teachers devote teaching reform. By reforming the students will gradually change the passive learning habit for a long time, actively participate in collecting materials, organizing documents, making PPT, participating in social research, team cooperation, and discussing and communicating with each other, etc. In the classroom, there is no longer only teacher "monologue", students are competing to speak and ask each other questions. The reform of classroom teaching mode will stimulate students to participate in various disciplines and professional competitions, and dare to participate in social practice. Learning is no longer confined to the ivory tower. 


\section{The Opportunity of Cooperative Learning Teaching Mode}

\section{The Teaching Mode of Cooperative Learning Is Becoming More and More Popular in the Reform Activities of Colleges and Universities}

In recent years, colleges and universities have paid more attention to the study of cooperative learning, and the study of cooperative learning and pilot programs and personnel are gradually increasing. The college teachers carry out the strategy research in combination with the professional teaching. Some college teachers research and explore some effective teaching strategiess uitable for this subject teaching actual need of cooperative learning, These studies focus on foreign language and management classes, there is less experience of cooperative learning in science and engineering courses, more emphasis on teaching procedures, there are few studies on teaching goal setting, teaching content reconstruction, teaching evaluation design and so on. Education researchers study of basic education of cooperative learning has more influence results, For example, the exploration of personality optimization teaching in the department of education of zhejiang university, cooperative teaching research and experiment of shandong training institute, and collaborative teaching experiment of the department of education of hunan university, etc. On the basis of the introduction and introduce foreign research results, the theoretical basis, characteristics and link of cooperative learning has a thorough interpretation, and to introduce the cooperation to the classroom teaching, provides guidance for the reform of teaching organization form, these results could be a reference for higher education.

\section{The University Creates a Good Working Environment, Which Guarantees Education Teaching Reform and Innovation}

Colleges and universities attach importance to the construction of classrooms and laboratories in teaching hardware and resources, such as the provision of mobile desks and chairs, and the installation of multimedia equipment. On the teaching resources, in addition to ensure that books and materials rich, also should strengthen the construction of digital library resources on the net, intensify the building of course website, provide favorable conditions for cooperative learning. On evaluation mechanism, the traditional way of teachers' subjective evaluation is changed, the evaluation view from the papers and research to the class, devote herself to guide teachers to cooperative learning. For a long time, the learning evaluation method of knowledge mastery of examination papers has been changed, the process of students' ability to grow is valued, the assessment of students with learning ability enhancement degree as the standard, pay attention to critical thinking and innovation consciousness. The assessment method is diversified, including test paper test, extracurricular study, classroom discussion, summary report, research report, PPT production, etc. Evaluation subjects are diverse, including teachers, students or students themselves. This kind of evaluation can make students' learning idea and habit change positively and become the master of learning [3,4].

\section{Students Need to Acquire Knowledge and Abilities in All Aspects}

With the advent of the era of global economic integration, the competition of talents has become increasingly fierce, and employers' expectations of the graduates' professional ability have been continuously improved. Employers pay more attention to the vocational ability of graduates instead of simple ideological quality and school performance. As college students, in addition to learn professional knowledge, also should efforts to expand own aspect of knowledge and learning ability through the minor, all kinds of knowledge lecture and a lot of reading extracurricular books. Students develop and train their social work ability, interpersonal skills and organizational coordination and cooperation ability through advanced means such as vocational ability training, so as to improve their comprehensive quality, strengthen the practice, optimize the knowledge structure and the intelligence accomplishment, train oneself to be the compound talented person with the liberal view, broad vision and comprehensive creativity. Students rely on their true professional skills to win employers' favor. Colleges and universities should promote the reform of education system of cooperative learning, optimize the structure of education resources, develop professional ability education, train graduates with a comprehensive career quality and active employment awareness, and help them win competition in the job market. 


\section{The Challenge of Cooperative Learning Teaching Model}

\section{Teachers Need to Improve Knowledge Structure and Update Teaching Methods}

The reform of teaching mode based on cooperative learning requires teachers to bring knowledge to students to bring students to knowledge. Teachers should allow students to experience the process and make the learning process a part of their life. In the teaching, teachers should constantly optimize the structure of knowledge, turn the teaching process into the process of guiding students to raise questions and solve problems, help students create the thinking patterns which build questions, collect information, analyze and deal with problems, and solve problem. In the teaching, teachers should help students initiative and creativity, provide a variety of opportunities in constructing knowledge, using knowledge and expressing themselves, enable students to form self-monitoring, self-reflection, self-evaluation and self-feedback through active learning [5].

\section{The Traditional Teaching Mode Impedes the Teaching Reform}

In the traditional teaching mode, teachers are the center of teaching activities and the main body of teaching activities. Teacher's teaching level, teaching skill and teaching art determine the students' learning effect. This kind of classroom teaching model has long been the mainstream mode of Chinese school teaching.

From the teacher's point of view, first of all, most of them gain knowledge in traditional teaching mode, or in traditional education. In the long-term teaching practice, they are familiar with knowledge of teaching and teaching methods, can easily finish the teaching task need not too much for classroom teaching design. Secondly, there are individual differences between different regions and schools. These individual differences will form different career ambition, sense of responsibility and teaching effect, the teachers' own moral training, learning grade, interests and way of thinking will be direct or indirect influence on students. Third, many teachers use books as the center and cram to impart knowledge. Fourthly, influenced by the traditional teaching mode, many teachers have rigid teaching methods and single teaching methods. Today, with the rapid development of science and technology, with the increase of teaching capacity and the continuous updating of knowledge, the traditional teaching methods are challenged.

From the perspective of students, first of all, under the traditional teaching mode, students receive knowledge passively through teachers' teaching. Students learning process is the process of accumulating knowledge, most of the students gradually develop a numb habit of which don't know what to ask why, thus forming a kind of idea of blind worship of the books and the teacher's. This kind of learning method not only restricts the development of students' thinking, but also causes them to lose the initiative of learning and even be forced to study. Secondly, the students' learning style is basically a preview - listen practice - review, the passive accept, rote learning, mechanical training method make students become the slaves of books, not only a lack of imagination and innovation spirit, also hard to sublimation. Third, under the current exam system, many students only pay attention to read with rigid, strive to get a high score in the exam, often ignore the cultivation of their various aspects ability, eventually leading to many students ability is low. Some students even limit their vision to schools and textbooks, and lack the necessary understanding of the development of the world and social change.

\section{Summary}

Through SWOT analysis, cooperative learning as an innovative teaching mode brings vitality to classroom teaching. It highlights the cooperative learning among students and analyzes and solves problems through collective intelligence and strength of collective groups. Cooperative learning provides a new way to cultivate students' sense of cooperation, cooperation ability and spirit of cooperation. By student feedback shows that as long as the teacher organizations appropriate, reasonable teaching content, students will gradually accept and like giving their views in discussion cooperation atmosphere, show their learning achievements. During the cooperative learning process, students learn to integrate themselves into the group. In order to achieve a learning goal, the team members study and explore each other, inspire each other and interact with each other.This way not only helps to cultivate the students' 
collective consciousness, cooperation skill and competitive spirit, and help to cultivate students' problem consciousness and the ability to question, fundamentally solve the problem that ignores student's initiative, consciousness and creativity, and promote the formation and development of the comprehensive qualities of interests, specialties, wills and behaviors, finally, to meet the needs of society, competent, high-quality talents.

\section{References}

[1] Tan Wang. Cooperative learning -- principle and strategy [M]. Beijing: XueYuan press, 2001.

[2] Rao Wu. SWOT analysis of case teaching method in social security teaching [J]. High education BBS, 2012(12), 81-83.

[3] Li-Qing Xu, Guo-Ying Qian, et al. Research status, problems and countermeasures of cooperative learning in universities [J]. Chinese university teaching, 2010(7), 82-84.

[4] Guo-Ying Qian. With the ability to develop as the core, training high-quality talents suitable for social needs [J]. Journal of ZheJiang WanLi college, 2008(11), 55-57.

[5] Guo-Ying Qian, et al. The ability to cultivate innovative talents and explore the teaching methods of cooperative learning [J]. Chinese university teaching, 2007(8), 20-22. 